${ }^{10}$ Fankhauser S, Herz G, Zuppinger K. Expériences avec l'insuline humaine chez des enfants diabétiques. Médecine et Hygiène 1982;40:1378-84.

11 Clark AJL, Knight G, Wiles PG, et al. Bio-synthetic human insulin in the treatment of diabetes. Lancet 1982;ii:354-7.

12 Tatpati OA, Guthries RA, Indulli-Tothic J. A comparison of biosynthetic human insulin (BHI) and Nordisk pork insulin (NPI) [Abstract]. Diabetes $1982 ; 31$, suppl $2: 174$.

${ }^{13}$ Holman RR, Turner RC. The basal plasma glucose: a simple, relevant index of maturity-onset diabetes. Clin Endocrinol 1981;14:279-86.

14 Jeppsson JO, Franzen B, Gaal AB. Simplified determination of HbAlc in diabetic patients by use of electrofocusing. In: Radola BJ, ed.
Electrophoresis '79; advanced methods, biochemical and clinical applications. Berlin, New York: de Gruyte, 1980:655-61.

15 Burstein M, Scholnick HR, Morfin R. Rapid method for the isolation of lipoproteins from human serum: precipitation with polyanions. $\mathcal{f}$ Lipid Res 1970;11:583-95.

${ }^{16}$ Ononogbu IC, Lewis B. Lipoprotein fraction by a precipitation method: a simple quantitative procedure. Clin Chim Acta 1976;71:397-402.

${ }^{17}$ Rupp WM, Barbosa JJ, Blackshear PJ, et al. The use of an implantable insulin pump in the treatment of type II diabetes. $N$ Engl $\mathcal{f}$ Med $1982 ; 307: 265-70$.

(Accepted 21 December 1983)

\title{
The sicca syndrome in thalassaemia major
}

\author{
C BORGNA-PIGNATTI，V CAMMARERI，P DE STEFANO, U MAGRINI
}

\begin{abstract}
A 20 year old man with $\beta$ thalassaemia developed symptoms of the sicca syndrome. His serum contained rheumatoid factor and antinuclear antibodies. $A$ biopsy specimen of labial salivary gland showed large accumulations of haemosiderin within the parenchymal cells of the acini.

Although in this case the sicca syndrome could not be definitely distinguished from Sjögren's syndrome, the patient's HLA type was not the one usually associated with Sjögren's syndrome. Histological appearances suggested that the causative factor of the sicca syndrome was iron overload owing to an intensive blood transfusion regimen.
\end{abstract}

\section{Introduction}

Iron overload has been reported to have produced the sicca syndrome, xerostomia, and xerophthalmia in a patient with idiopathic haemochromatosis. ${ }^{1}$ We report here the first case of the sicca syndrome in a young adult with $\beta$ thalassaemia major and severe iron overload owing to repeated blood transfusions.

\section{Case report}

The patient was a 20 year old man in whom $\beta$ thalassaemia major had been diagnosed at the age of 1 year. Transfusions were started a month later and continued up to the time of writing at intervals of one to two months. The mean haemoglobin concentration before transfusion had not been below $9.3 \mathrm{~g} / \mathrm{dl}$ throughout the past three years. We calculated from clinical records that he had received a total of over $100 \mathrm{l}$ blood, containing about $50 \mathrm{~g}$ iron. Splenectomy was performed at age 3 . There was no history of viral hepatitis. Chelation treatment was started in 1975 with desferrioxamine mesylate intramuscularly, $500 \mathrm{mg} /$ day five days a week; from the beginning of 1980 he self administered an average dose of $2 \mathrm{~g}$ desferrioxamine mesylate subcutaneously over eight hours on alternate days. In the past year, in an attempt to reduce the iron load, he had undergone

University of Pavia, Ospedale San Matteo, 27100 Pavia, Italy C BORGNA-PIGNATTI, MD, senior researcher in paediatrics V CAMMARERI, $M D$, paediatric resident $P$ DE STEFANO, MD, paediatric house officer U MAGRINI, MD, professor of pathology

Correspondence to: Dr C Borgna-Pignatti, Department of Paediatrics, University of Pavia, Ospedale San Matteo, 27100 Pavia, Italy. monthly wash outs with intravenous desferrioxamine mesylate, 300 $\mathrm{mg} / \mathrm{kg} / 24 \mathrm{~h}(16 \mathrm{~g} / 24 \mathrm{~h})$. In 1981 , at age 19 , he developed diabetes requiring insulin treatment. In July 1982 he had an episode of cardiac failure, which responded readily to diuretics and digitalis. Puberty did not develop spontaneously, and he was therefore given human chorionic gonadotrophin with some improvement in sexual maturation.

In April 1983 he complained of dry mouth and itchy eyes of a few weeks' duration. Pertinent clinical findings, apart from a dry scaly tongue, included moderately hyperpigmented skin and a large, hard liver palpable $7 \mathrm{~cm}$ below the right costal margin. No swelling of the parotid or lachrymal gland was noticeable. Liver function tests showed an alanine transferase activity three times the upper limit of normal, prothrombin activity $50 \%$ of normal, albumin concentration $35 \mathrm{~g} / \mathrm{l}$, and gammaglobulin concentration $3.2 \mathrm{~g} / 100 \mathrm{ml}$. Serum was negative for hepatitis $B$ surface antigen and anti-e antibodies and positive for anti-s and anti-c antibodies. Fibrinogen concentration was $2.8 \mathrm{~g} / \mathrm{l}$. Rheumatoid factor was present in the serum, and antinuclear antibodies were present at a titre of $1 / 500$, with a speckled pattern. No organ specific antibodies were found. HLA typing showed B13, Bw35, DR5, and DR7. The serum ferritin concentration was 3.3 $\mu \mathrm{g} / \mathrm{l}$, and the average urinary excretion of iron after subcutaneous desferrioxamine mesylate was $645 \mu \mathrm{mol}(36 \mathrm{mg}) / 24 \mathrm{~h}$; excretion doubled when the high intravenous dose was administered. Faecal excretion of chymotrypsin was below normal. Schirmer's test gave a result of $3 \mathrm{~mm}$.

Ophthalmological examination with fluorescein showed areas of abnormal epithelial cells on the cornea. A biopsy specimen of the labial salivary gland showed large accumulations of haemosiderin within the parenchymal cells of the acini. There was no evidence of lymphocytic infiltrate, cellular destruction, or interstitial fibrosis (figure).

Treatment with bromhexine and artificial tears was prescribed with little subjective improvement.

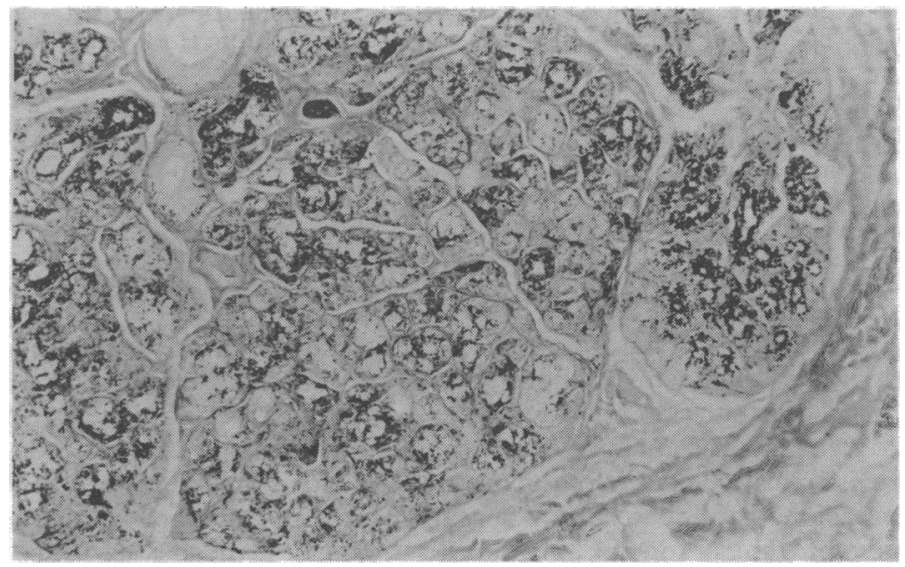

Specimen of labial gland. The salivary acini are filled with haemosiderin granules. (Perl's stain. $\times 43$.) 


\section{Comment}

Most pathological manifestations of thalassaemia major are attributed to haemosiderosis owing to transfusions. Iron deposits in the heart, liver, pancreas, and endocrine glands have been described. ${ }^{2}$ In this patient with the sicca syndrome we found heavy deposition of iron in the labial salivary glands similar to that described in a woman with idiopathic haemochromatosis. ${ }^{1}$ We were unable to distinguish the syndrome from Sjögren's syndrome on clinical grounds. Sjögren's syndrome is an autoimmune disorder affecting mainly postmenopausal women. It is the result of lymphocyte mediated destruction of the exocrine glands and can occur alone or in association with another connective tissue disorder, most commonly rheumatoid arthritis. Our patient never had symptoms of connective tissue disease or enlargement of the parotid gland. His HLA type was not the one (B8 and DR3 or 4) usually associated with Sjögren's syndrome. Thyroid autoantibodies were not present. He did have hypergammaglobulinaemia and was positive for rheumatoid factor and antinuclear antibodies. High concentrations of gammaglobulin, however, are almost invariably present in patients with thalassaemia, ${ }^{3}$ and rheumatoid factor and antinuclear antibodies have been found in $31 \%$ and $13 \%$ respectively of a series of unselected patients with $\beta$ thalassaemia major ${ }^{4}$ and have been attributed to the repeated antigenic stimuli received with transfusions. The histological appearance of the salivary glands, with heavy deposition of iron in glandular acini and absence of lymphocytic infiltration, did not support a diagnosis of Sjögren's syndrome but suggested damage related to iron.

Although we could not with certainty rule out associated autoimmune disease, we are inclined to regard the sicca syndrome in our patient as a consequence of iron overload. Disease of the exocrine portion of the pancreas leading to reduced serum chymotrypsin concentrations has been described in patients with thalassaemia and has been attributed to infiltration of the acinar tissue by iron. ${ }^{5}$ With the improvement in life expectancy due to intensive transfusion regimens and aggressive chelation of iron, doctors taking care of patients with thalassaemias are likely to see new symptoms developing in this previously non-existent population of adult patients. The sicca syndrome may be one of them.

Professor G Veneroni, Centro Trasfusionale, Ospedale Fatebenefratelli, performed the HLA typing.

\section{References}

1 Blandford RL, Dowdle JR, Stephens MR, Walker DM. Sicca syndrome associated with idiopathic haemochromatosis. $\mathrm{Br}$ Med $\mathcal{F} 1979 ; \mathrm{i}: 1323$.

2 O'Brien RT. Iron overload: clinical and pathologic aspects in pediatrics. Semin Hematol 1977;15:115-25.

3 Tovo PA, Miniero R, Barbera C, Sacchetti L, Saitta M. Serum immunoglobulins in homozygous beta-thalassemia. Acta Haematol (Basel) $1981 ; 65: 21-5$.

4 Economidou J, Pathouli C, Hadziyannis S, Fostiropoulos G, Constantoulakis M. Complement levels in relation to certain antibodies in polytransfused thalassaemic patients. Vox Sang 1976;31, suppl 1: 32-8.

${ }^{5}$ Hussain MAM, Dandona P, Fedail SS, Ramdial L, Flynn D, Hoffbrand AV. Serum immunoreactive trypsin in beta-thalassaemia major. $\mathrm{f} \mathrm{Clin}$ Pathol $1981 ; 45: 970-1$.

(Accepted 24 November 1983)

\title{
Glycosylation of hair: possible measure of chronic hyperglycaemia
}

\author{
R B PAISEY, J R CLAMP, M J C KENT, N D LIGHT, M HOPTON, M HARTOG
}

\begin{abstract}
To determine whether hair is excessively glycosylated in diabetes mellitus $4 \mathrm{~cm}$ hair samples were taken proximally from behind the ear in 50 white non-diabetics and 46 diabetics. Hair glycosylation was assayed by a modification of the thiobarbituric acid reaction. Blood was taken from the diabetics at the same time for measurement of glycosylated haemoglobin concentration.

The mean (1 SD) concentration of fructosamine ( $\mu \mathrm{mol} / 100 \mathrm{mg}$ hair) was 0.054 (0.011) for normal hair. Glycosylation was not related to sex, age, or hair colour. The diabetics' hair was more heavily glycosylated $(0.097(0.045))$ than normal $(p<0.01)$ and there was a
\end{abstract}

University Department of Medicine, Bristol Royal Infirmary, Bristol BS2 8HW

R B PAISEY, MRCP, lecturer in medicine

J R CLAMP, MD, professor of experimental medicine

M HOPTON, research technician

M HARTOG, FRCP, reader in medicine

ARC Meat Research Institute, Langford, Nr Bristol, Avon BS18 7DY M J C KENT, DPHIL, research associate

N D LIGHT, PHD, head of collagen section

Correspondence to: Dr R B Paisey. correlation between hair glycosylation and the concentration of glycosylated haemoglobin in the diabetics $(\mathbf{r}=0.71 ; p<0.01)$. Hair from non-diabetics showed a stable time related increase in glycosylation when incubated with glucose.

Glycosylation of hair might provide a stable long term measure of tissue glycosylation, useful in the investigation of microvascular complications of diabetes mellitus.

\section{Introduction}

The discovery of increased non-enzymatically glycosylated haemoglobin concentrations in diabetes mellitus ${ }^{1-4}$ has led to intensive research into similar excess glycosylation of other tissue proteins, especially in an attempt to establish a link between this process and chronic complications of the condition. Measurement of the percentage concentration of glycosylated haemoglobin has proved useful in assessing diabetic control, but tissue collagen, which is susceptible to functional changes from excessive glycosylation, has a much slower rate of turnover than haemoglobin. ${ }^{5}$ It is therefore of interest to investigate possible longer term markers of hyperglycaemia than haemoglobin, and we have conducted such a study.

As it is not feasible repeatedly to sample tissues containing basement membrane from the same subject, we investigated the 